\title{
Regularities of Seismicity of Western and Central Uzbekistan (Southwestern Part of Western Tien-Shan Region)
}

\author{
Makhira T. Usmanova1, Abdusattor M. Sattarov² \\ ${ }^{1}$ Institute of Seismology Named after G. A. Mavlyanov of the Academy of Sciences of Uzbekistan, Tashkent, Uzbekistan \\ ${ }^{2}$ Northeastern University, Boston, USA \\ Email:m.usmanova@mail.ru, sattarov.a@northeastern.edu, sattarov199930@gmail.com
}

How to cite this paper: Usmanova, M.T. and Sattarov, A.M. (2021) Regularities of Seismicity of Western and Central Uzbekistan (Southwestern Part of Western Tien-Shan Region). Open Journal of Earthquake Research, 10, 153-163.

https://doi.org/10.4236/ojer.2021.104010

Received: March 2, 2021

Accepted: November 27, 2021

Published: November 30, 2021

Copyright (C) 2021 by author(s) and Scientific Research Publishing Inc. This work is licensed under the Creative Commons Attribution International License (CC BY 4.0).

http://creativecommons.org/licenses/by/4.0/

\begin{abstract}
The paper discusses the spatial and temporal distribution of seismic activity in the southwestern part of the Western Tien Shan. The study identifies four groups of strong earthquakes that occurred in Western and Central Uzbekis$\tan$. The regularity of redistribution of the accumulated tectonic energy in the form of shuttle migration of seismicity with the recurrence rate of a group of strong earthquakes has been revealed. The synchronicity of periods of seismic activation of the Western Tien Shan (regional structure) and the Asian part of the Mediterranean-Asian seismic belt (structure of a large-regional scale) was found. At the same time, deviations from synchronicity are noted in the form of delays in the periods of seismic activation between the considered structures. The seismicity study revealed a deviation from the regularity of grouping of strong earthquakes in the seismic regime of the region. This was observed in the Gazli earthquakes. The strongest triple Gazli earthquakes of 1976 and 1984 with $M=7.0-7.3$ were preceded by natural and technogenic triggers. Natural triggers included active fracturing (large fractures up to 100 $\mathrm{km}$ in length) in the north of Tamdybulak area, the absence any of tangible earthquakes in the epicentral area of Gazli for more than 40 years, and the appearance of small mud volcanoes-griffins before a strong earthquake. The technogenic triggers included a 40-year gas pumping at the Gazli fields and two underground nuclear explosions in 1966 (\#273) and 1968 (\#142) produced near the epicenter of the tectonic Gazli earthquakes of 1976 and 1984.
\end{abstract}

\section{Keywords}

Strong Earthquakes, Shuttle Migration of Seismicity, Cyclic Recurrence of Large Earthquakes, Natural and Technogenic Triggers 


\section{Introduction}

The paper considers the development of regional seismicity in the Western Tien-Shan and the Turan platform [1]-[8]. Uzbekistan is located on the Turan platform and is conventionally divided by geologists into Western, Central, and Eastern Uzbekistan. The seismicity of Uzbekistan territory is also considered in the context of the geolocation of Western, Central and Eastern Uzbekistan.

In terms of seismicity, Eastern Uzbekistan is one of the highly dangerous seismic territories in Uzbekistan. In this part of Uzbekistan, earthquakes with seismic intensity $I_{0}=9-10$ balls (by MSK-64 Scale) can occur. The last strong Chatkal earthquake occurred on November 02, 1946, $M=7.6, I_{0}=9-10$ balls, in the Talas-Fergana fault zone. At the southern end of this giant Talas-Fergana fault, in 1902 there was a Kashgar earthquake with $\mathrm{M}=8.1, \mathrm{I}_{0}=10$ balls [9] [10]. Figure 1 shows distribution of the epicenters of earthquakes with $M \geq 3.5$ that occurred in Central Asia in the period from 2000 BC to 2017 AD [9] [11] [12] [13]. The important elements shown on Figure 1 are two almost latitudinal bands of epicenters concentration (marked in black), clearly distinguished in the south. These bands indicate the location of the Pamir-Hindu-Kush deep-focus earthquakes, reaching depth of up to $300 \mathrm{~km}$ and indicate the place of intracontinental subduction of the Eurasian and Indian tectonic plates. Analysis of the Catalog of strong earthquakes showed that Eastern Uzbekistan acts as a single block of the earth's crust, where strong earthquakes with a magnitude of $M=5.0$

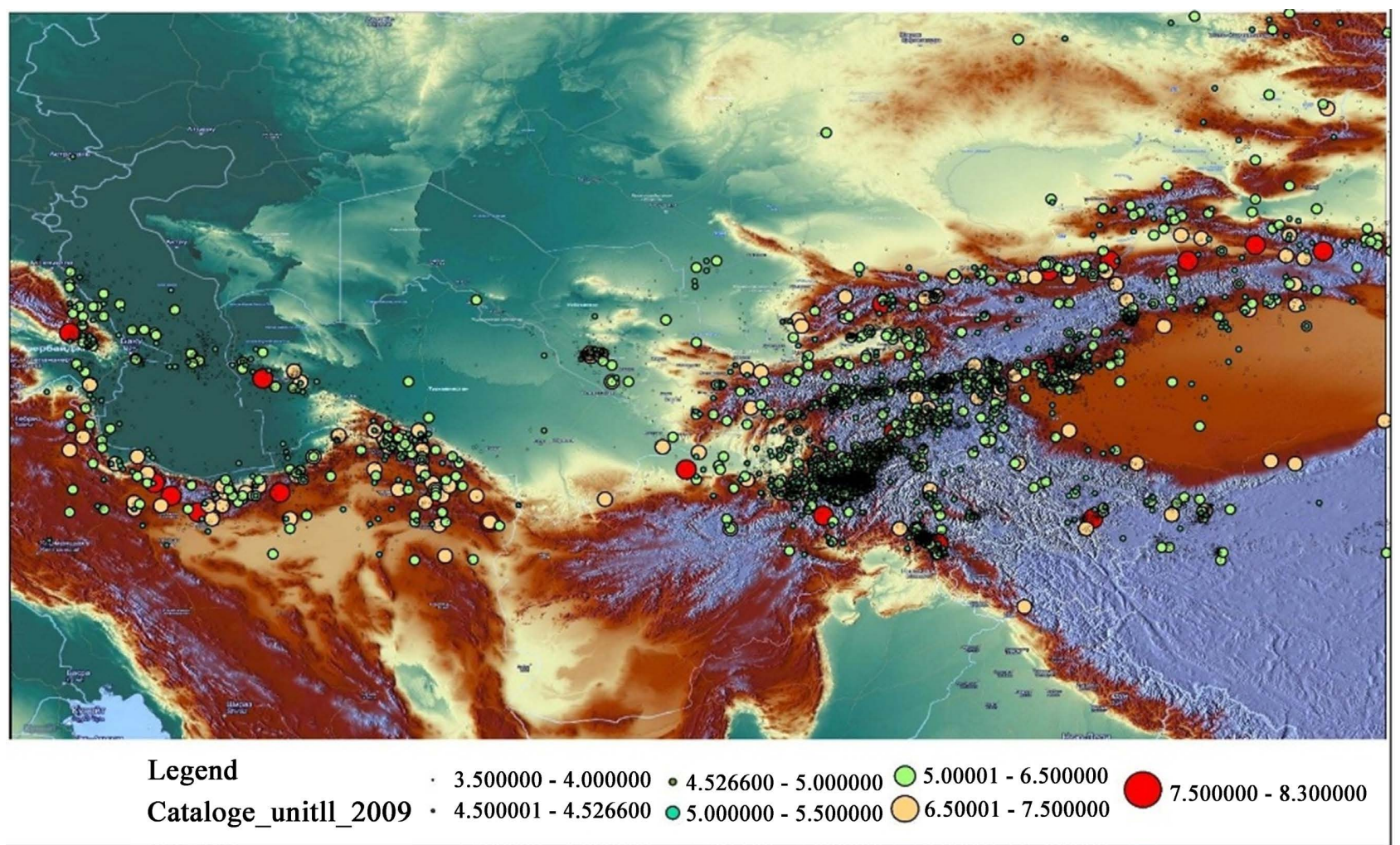

Figure 1. Map of epicenters of earthquakes with magnitude of $M \geq 3.5$ in Central Asia during 2000 BC - 2009 AD [Usmanova, M.T. and Shukurov, Z.F., 2016]. 
$\div 6.9$ are located in the area seismogenic zones, i.e. in zones of regional faults [14] [15] [16]. At the same time, earthquakes with a magnitude of $M=7.0 \div 7.5$ are located at the intersections of large faults.

Regarding Western and Central Uzbekistan, the analysis of the Catalog of strong earthquakes and studies of the regional seismicity revealed that strong earthquakes with a magnitude of $M \geq 5.0$ are distributed unevenly. The epicenters of these strong earthquakes have signs of grouping in space and time and are distinguished into four groups of strong earthquakes (Table 1) [9] [10] [11] [12] [13]. According to the seismic activity signs, the study region also has divided into two parts, Western and Central Uzbekistan. Western and Central Uzbekistan, including the Central Kyzyl Kum desert, are classified as dangerous seismically active regions of Uzbekistan. In these territories, in the distant past, there were Bukhara earthquakes of 942, 1390, 1821 and 1822 with magnitude of M 7.0 and nowadays, the well-known catastrophic Gazli earthquakes of 1976 and 1984 with magnitude of $M \geq 7.3$ ( $\mathrm{I}_{0}=9$ - 10 balls) [4] [5] [9] [15].

The study area is located in the southwestern part of the Western Tien-Shan and the Turan platform, where seismic activity has been controlled by the system of deep tectonic faults of Western Tien-Shan [1] [3] [14].

The first studies of the frequency of strong earthquake recurrence in the Western Tien-Shan were carried out by R.N. Ibragimov and K.N. Abdullabekov [15], who identified seven seismotectonic regions and analyzed their manifestation of seismic activity. The findings revealed that in all seismotectonic areas, strong earthquakes manifested cyclically, with a distinctive time of $\mathrm{T}=40_{\text {act.phase }}$ $\pm 10-15$ years and $\mathrm{T}=40_{\text {pass.phase }}=25-30$ years [15].

\section{The Spatial-Temporal Distribution of Earthquakes in Western and Central Uzbekistan}

\subsection{The Main Regularities of Seismic Activation}

As was discussed above, the analysis of the Catalog of strong earthquakes in the study area (Western and Central Uzbekistan) showed that strong earthquakes with a magnitude of $M \geq 5.0$ are unevenly distributed and the epicenters of these strong earthquakes have signs of spatial and temporal grouping [9] [10] [11] [12] [13].

The Bayesian method was used to calculate the probabilities of quiescence and activation in two neighboring regions, Western and Central Uzbekistan [17]. During the statistical analysis, the probability calculations were not carried out for the $1^{\text {st }}$ group due to the lack of information. Data on historically strong earthquakes occurred within the period specified for $1^{\text {st }}$ group have not been preserved for the following reasons:

- Possible skipping of strong earthquakes due to erosion/aeolian/denudation typical for the deserts and steppes of Western Uzbekistan (Kyzyl-Kum, partly the Karakum deserts);

- Climatic anomalies that erased the traces of past paleohistorical seismic shocks; 
Table 1. Distribution of groups of strong earthquakes in time and over Western and Central Uzbekistan.

\begin{tabular}{|c|c|c|c|c|c|}
\hline No. & Group & $\begin{array}{l}\text { Seismic } \\
\text { activity } \\
\text { period }\end{array}$ & Western Uzbekistan (West) & Central Uzbekistan (East) & $\begin{array}{l}\text { Probability onset of seismic } \\
\text { activity with earthquake } \\
\text { groups } P(t)\end{array}$ \\
\hline 1 & I & $900-1400$ & $\begin{array}{l}\text { Strong Bukhara earthquakes of } 942 \\
\text { and } 1390 \text { with } \mathrm{M} \approx 7.0\end{array}$ & $\begin{array}{l}\text { Seismic quiescence; absence of } \\
\text { strong earthquakes with } M \geq 5.0\end{array}$ & - \\
\hline 2 & & $\begin{array}{l}1400-1818 \\
(1800-1818)\end{array}$ & $\begin{array}{l}\text { Seismic quiescence; absence of } \\
\text { strong earthquakes with } M \geq 5.0\end{array}$ & $\begin{array}{l}\text { Strong Samarkand earthquakes of } \\
1490,1799,1817 \text { and } 1818 \text { with } \mathrm{M} \\
=5.0-6.1\end{array}$ & - \\
\hline 3 & II & $1821-1892$ & $\begin{array}{l}\text { Strong Bukhara and Kyzyl-Kum } \\
\text { earthquakes of } 1821,1822 \text { and } \\
1892 \text { with } M=6.4-7.0\end{array}$ & $\begin{array}{l}\text { Seismic quiescence; absence of } \\
\text { strong earthquakes with } M \geq 5.0\end{array}$ & $\begin{array}{l}\text { Probability of occurrence of } \\
\text { earthquakes in Western } \\
\text { Uzbekistan: } \mathrm{P}(\mathrm{t})=2.941 \%\end{array}$ \\
\hline 4 & & $1897-1923$ & $\begin{array}{l}\text { Seismic quiescence; absence of } \\
\text { strong earthquakes with } M \geq 5.0\end{array}$ & $\begin{array}{l}\text { Strong Uratyube earthquakes of } \\
\text { 1897, } 1897 \text { and 1902; } \\
\text { Matchin earthquake of } 1923 \text { with } \\
M=5.7-6.7\end{array}$ & $\begin{array}{l}\text { Probability of occurrence of } \\
\text { earthquakes in Central } \\
\text { Uzbekistan: } \mathrm{P}(\mathrm{t})=2.855 \% \\
\text { Probability of occurrence of } \\
\text { earthquakes in Central } \\
\text { Uzbekistan if there are no } \\
\text { earthquakes in Western } \\
\text { Uzbekistan: } \mathrm{P}(\mathrm{t})=2.941 \%\end{array}$ \\
\hline 5 & III & $1928-1934$ & $\begin{array}{l}\text { Earthquakes of } 3 \text { January 1928, } 11 \\
\text { July } 1928 \text { and } 1929 \text { year; } \\
\text { Tamdybulak earthquakes of } 1932 \\
\text { and } 1934 \text { year with } M=5.2-6.2\end{array}$ & $\begin{array}{l}\text { Seismic quiescence; absence of } \\
\text { strong earthquakes with } M \geq 5.0\end{array}$ & $\begin{array}{l}\text { Probability of occurrence of } \\
\text { earthquakes in Western } \\
\text { Uzbekistan: } \mathrm{P}(\mathrm{t})=10.526 \%\end{array}$ \\
\hline 6 & & $1940-1966$ & $\begin{array}{l}\text { Seismic quiescence; absence of } \\
\text { strong earthquakes with } M \geq 5.0\end{array}$ & $\begin{array}{l}\text { Earthquake of } 1940 \text {, Bakhmal-(1) } \\
\text { earthquake of } 1955 \text {, Koshtepa } \\
\text { earthquake of } 1965 \text { and Tashkent } \\
\text { earthquake of } 1966 \text { with } \mathrm{M}=5.2 \text { - } \\
5.5\end{array}$ & $\begin{array}{l}\text { Probability of occurrence of } \\
\text { earthquakes in Central } \\
\text { Uzbekistan: } \mathrm{P}(\mathrm{t})=9.418 \% \\
\text { Probability of occurrence of } \\
\text { earthquakes in Central } \\
\text { Uzbekistan if there are no } \\
\text { earthquakes in Western } \\
\text { Uzbekistan: } \mathrm{P}(\mathrm{t})=10.526 \%\end{array}$ \\
\hline 7 & IV & $1968-1984$ & $\begin{array}{l}\text { Kyzyl-Kum earthquakes of } 13 \text { and } \\
14 \text { March } 1968 \text { y.; Gazly } \\
\text { earthquakes of } 8 \text { April 1976, } 17 \\
\text { May } 1976 \text { and } 19 \text { March } 1984 \text { with } \\
\text { M= } 5.1-7.3\end{array}$ & $\begin{array}{l}\text { Seismic quiescence; absence of } \\
\text { strong earthquakes with } M \geq 5.0\end{array}$ & $\begin{array}{l}\text { Probability of occurrence of } \\
\text { earthquakes in Western } \\
\text { Uzbekistan: } \mathrm{P}(\mathrm{t})=6.122 \%\end{array}$ \\
\hline 8 & & 2013-2017 & $\begin{array}{l}\text { Seismic quiescence, strong } \\
\text { earthquakes with } M \geq 5.0 \text { absence }\end{array}$ & $\begin{array}{l}\text { Marjanbulak earthquake of } 2013 \text {, } \\
\text { Kitab earthquake of } 2016 \text { and } \\
\text { Bakhmal-(2) earthquake of } 2017 \\
\text { with } \mathrm{M}=5.1-6.2\end{array}$ & $\begin{array}{l}\text { Probability of occurrence of } \\
\text { earthquakes in Central } \\
\text { Uzbekistan: } \mathrm{P}(\mathrm{t})=5.748 \% \\
\text { Probability of occurrence of } \\
\text { earthquakes in Central } \\
\text { Uzbekistan if there are no } \\
\text { earthquakes in Western } \\
\text { Uzbekistan: } \mathrm{P}(\mathrm{t})=6.122 \%\end{array}$ \\
\hline
\end{tabular}

- Lack of settlements.

For the other three groups, the probabilities for the prohibition of seismicity 
quiescence/activity at certain periods were calculated. Distribution of groups of strong earthquakes with magnitude $M \geq 5.0$ in time and over Western and Central Uzbekistan for the 1821-2017 is provided in Table 1.

The Bayesian methodology was used to calculate the probability of earthquake occurrence in time (years) [17]. Moreover, if there were two earthquakes in one year, then this year was calculated as one year with earthquakes, since onset of the time of seismic activity is considered. At the same time, the calculations included the impact of the seismic activities of two regions, Western Uzbekistan and Central Uzbekistan. In general, the calculations confirmed the periodic onset of seismic activity, leading alternately to the formation of strong earthquakes groups in Western and Central Uzbekistan.

According to the Gutenberg-Richter earthquake recurrence law, the recurrence periods of earthquakes with different magnitudes are determined by the logarithmic values of the seismic cycle duration. Using this methodology, the following estimates of the earthquake recurrence periods were calculated for the Western Tien-Shan (Tseis.cycle) [18] [19]:

- earthquakes with $M \geq 8.0 \quad$ - Tseis.cycle $=1000 \pm 283$ years;

- earthquakes with $M \geq 7.0 \leq 7.5 \quad$ - Tseis.cycle $=154.0 \pm 51.3$ years;

- earthquakes with $M \geq 5.5 \leq 6.1 \quad$ - Tseis.cycle = $49.0 \pm 15.6$ years;

- earthquakes with $M \geq 5.0 \quad$ - Tseis.cycle $=12.3 \pm 2.7$ years.

It is noted that the closer the study period is to the time of continuous operation of seismic stations in the region, the better the probabilistic estimates of earthquakes' onset.

Comparison of the seismic activity of Western and Eastern regions (Table 1) reveals the regularity of the alternate redistribution of the accumulated tectonic energy between these regions. As if some kind of "pendulum" operating on the "domino" principle creates a group of strong earthquakes around one strong earthquake with magnitude of $M=5.1 \div 7.3$. Seismic activation at regular intervals migrates from west to east in the central part of Uzbekistan and back to the west. During the seismic activity of Western Uzbekistan, a seismic quiescence has observed in the east of Central Uzbekistan. Then seismic activity migrates to the east, and a seismic quiescence occurs in the west. Such cyclicity of seismic activity migration is shuttle. Provided that, the energy threshold, i.e. the magnitude of strong earthquakes, in Western Uzbekistan is one unit of magnitude higher than in the east of Central Uzbekistan [10]. The "shuttle" migration of seismicity with 18 - $22 \mathrm{~km} /$ year in Eastern Uzbekistan was identified and studied by scholars [5] [7] [20] [21].

\subsection{Connection of Seismic Activity of Western and Central Uzbekistan with Large Regional and Planetary Seismotectonic Structures}

It is important to consider how the identified "shuttle" migration of seismic activity in Western and Central Uzbekistan correlates with large regional and planetary seismotectonic structures. 
The researchers [13] [15] [18] [22] [23] studied the seismicity of the Central Asia region considering the recurrence of seismic activity cycles in the Asian part of the Mediterranean-Asian seismic belt (Figure 2). They note that the Central Asian region has entered a seismically active phase since 2007, which may last until 2023. At this time, the probability of strong earthquakes in this region remains relatively high.

Strong earthquakes that occurred along the Mediterranean-Asian seismic belt seismically active phase with cycle $\mathrm{T}$ duration cycle of $\sim 17$ years, began in 2008 with an earthquake in the Aegean Sea (Greece) with magnitude of $M=7.3$. Then, on August 24, 2016, the earthquake with $M=6.2$ occurred in Accumoli (Italy). In 2017, the earthquake with $M=6.5$ occurred on the islands of Greece (Figure 2). Recently, on October 30, 2020, a strong earthquake with $M=6.7$ (USGS $M=7.0$ ) occurred in the Aegean Sea, in the Izmir province (Turkey). This indicates the ongoing seismic activity of the seismic belt.

The next seismic activity of 2007-2023, experienced by the Central Asian region, is reflected in Uzbekistan through a series of strong earthquakes during 2011-2017, with a general increase in the seismic background. During this period, in the Western Tien-Shan where located Uzbekistan, several strong earthquakes occurred: Kansk earthquake of 20.07.2011 with magnitude of $\mathrm{M}=6.3$, I = 8 balls (by MSK-64 Scale); Tuyabuguz earthquake of 2013 with magnitude of $M$ $=5.6, \mathrm{I}=7$ balls; Marzhanbulak earthquake of 2013 with magnitude of $\mathrm{M}=6.3$, I $=8$ balls; Kitab earthquake of 2016 with magnitude of $\mathrm{M}=5.1, \mathrm{I}=5$ balls; Bakhmal earthquake of 2017 with magnitude of $M=5.1, I=6$ - 7 balls [24] [25] [26].

A comparison of seismicity activity periods in the region regarding the Asian part of the Mediterranean-Asian seismic belt (Figure 2) is presented in Table 2.

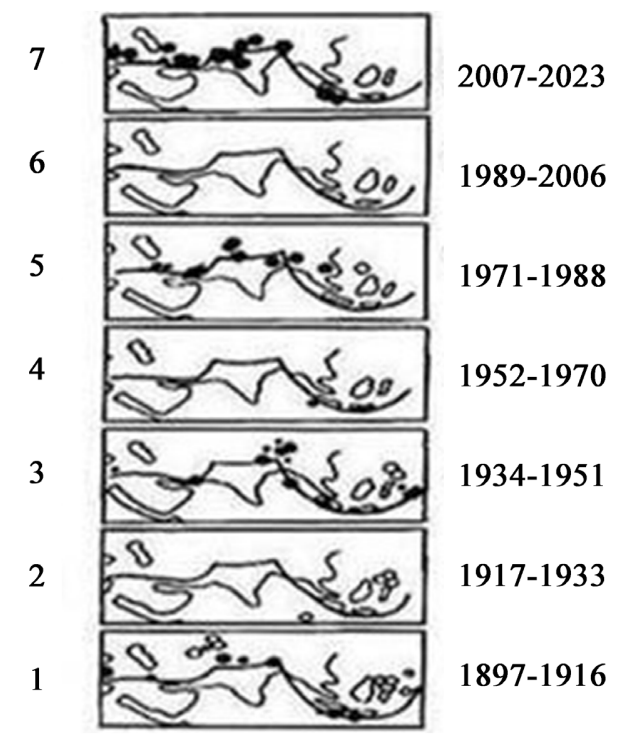

Figure 2. Peculiarities of manifestation of seismicity of Asian part of the Mediterranean-Asian seismic belt (up to 1970 according to [K. Mogi, 1974]; from 1971 to present days [K.N. Abdullabekov, M.T. Usmanova, 2003, 2008, 2016]). 
Table 2. Comparative characteristics of periods of seismic activation in the Western Tien-Shan and the Asian part of the Mediterranean-Asian seismic belt.

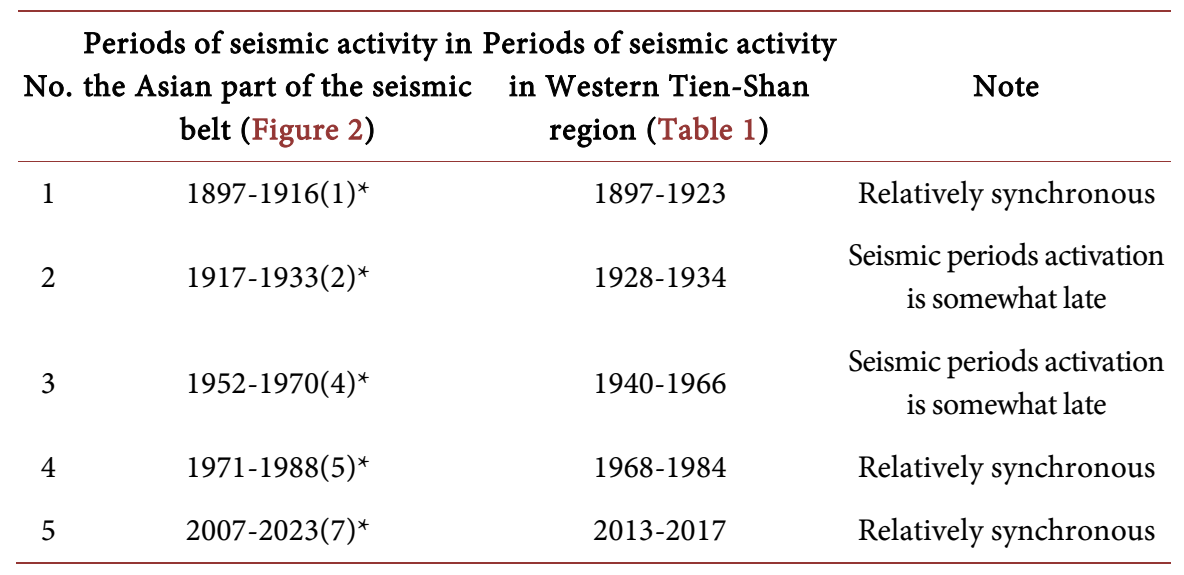

Note: $(1)^{\star}$-numbers of stages of seismic cycles.

As shown in Table 2, there is a synchronicity of periods of seismic activation of two structures: Western Tien-Shan (regional) and Asian part of the seismic belt (large regional, planetary scale). Deviations from synchronicity in the form of a lag in the seismic activation period of 1952-1970/1940-1966 can be explained by the low magnitude level $\mathrm{M} \sim 5.3$ of the main earthquake of the group, i.e. the fact that these earthquakes were ordinary in relation to events of a planetary scale.

\subsection{Deviations from the Identified Regularities of Seismic Activity of the Study Area}

During the data collation of the Catalog of Earthquakes of Uzbekistan, besides the four groups of strong earthquakes described above, the strong earthquakes with magnitude of $M \geq 5.0$, which did not fit into the established regularities of the seismic regime of the studied territory, were identified. These earthquakes include the well-known Gazli earthquakes. In this regard, the possible technogenic and natural causes of deviation from the regional seismicity were analyzed.

According to the Catalog of nuclear explosions, created at the Kazakhstan National Data Center [https://www.kndc.kz/], the dates of two nuclear test explosions carried out in Uzbekistan were identified: 1) 30 September 1966 with $\mathrm{M}=$ 5.1 (N 273) and 2) 21 May 1968 with $M=5.1$ (N 142). Subsequently, seismic events that showed deviations from the regional seismic regime possibly were associated to these nuclear explosions.

A possible connection between the activity of strong earthquakes and nuclear explosions through the impact of nuclear explosions on the geodynamic regime of the region, as well as through the impact of other technogenic and natural events, cannot be ruled out. Therefore, the last three strong Gazli earthquakes of 1976 and 1984 with a magnitude of up to $M=7.3$, which had a tectonic nature, should be also considered in the region. It should be noted that detailed work was carried out on the initiating effect of UNEs (underground nuclear explo- 
sions) produced at the Semipalatinsk, Novaya Zemlya, and Nevada test sites on the earthquakes in Central Asia. The most pronounced manifestations of the Pamir-Hindu-Kush and Tien-Shan earthquakes were the response of seismicity to UNE in the Central Asia region [27].

The northern part of Western Uzbekistan in the 50s of the last century was considered to be weakly seismic, and the Gazli earthquakes that occurred were a kind of surprise [1] [3] [4] [5] [14]. However, a retrospective analysis of the geological, geophysical and seismological data of the region made it possible to assume that geodynamic processes and technogenic events that have taken place over the past 100 years in the Gazli region could create preconditions for the Gazli earthquakes [10].

Among these prerequisites the most significant are:

1) Activation of fracturing with giant cracks up to $100 \mathrm{~km}$ long, up to $1 \mathrm{~m}$ wide, and $1-2 \mathrm{~m}$ deep in the area of the Tamdybulak village in 1965 (Figure 3) (natural trigger).

2) Absence of tangible earthquakes for more than 40 years in the epicentral region of Gazli earthquakes (natural trigger).

3) Appearance of linearly built small mud volcanoes- "griffins" in the epicentral area within 2 - 3 years (natural trigger).

4) Active and continuous 40-year gas pumping in the group of Gazli fields (technogenic trigger).

5) Underground nuclear explosions (technogenic trigger).

\section{Conclusions}

The following main regularities of the seismic regime of Western and Central Uzbekistan have been identified:

1) Four groups of strong earthquakes with $M \geq 5.0$ have been identified, which occurred in 1821-2017 and united around the "main" seismic shock with

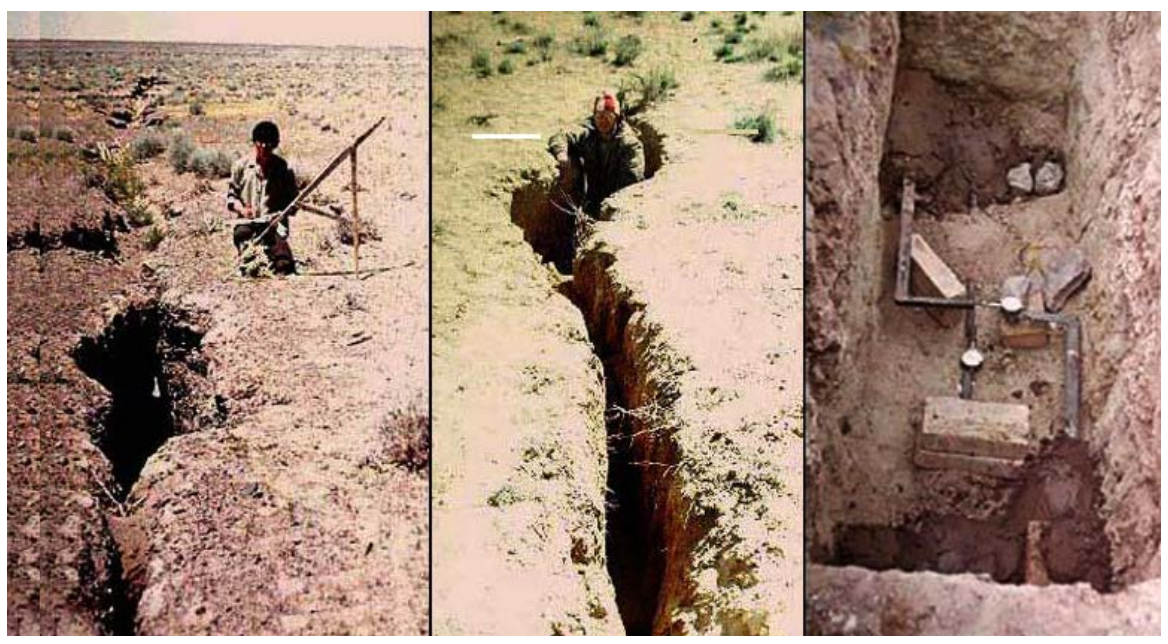

Figure 3. Kyzyl-Kum Desert, 1973. Monitoring of the deformation process of preparation the largest of Gazli earthquakes 1976, 1984, $\mathrm{M}=7.0-7.3$ on the Turan plate (from the archive of V.I. Ulomov). 
$M=5.1-7.3$. During the seismic activity of Western Uzbekistan, in the east of Central Uzbekistan there is a seismic quiescence and a return by shuttle migration of seismic activity to the east of Central Uzbekistan. In the same period, a seismic quiescence is observed in Western Uzbekistan. The shuttle migration of seismic activity in the region is periodically repeated by seismic cycles.

2) During the active seismic phase with cycle duration $T_{\text {length cycle }} \sim 17-18$ years, a group of strong earthquakes has formed and occurs. The duration of the passive phase cycle is also $\mathrm{T}_{\text {length cycle }} \sim 17-18$ years. The energy threshold, the magnitude of strong earthquakes in Western Uzbekistan is one unit of magnitude higher than in the east of Central Uzbekistan.

3) Heterogeneous composition of shocks in groups complicates interpretation. There is a "main" strong shock with different magnitude values (from $M=5.0$ to $\mathrm{M}=7.3$ ) and with varying return periods.

4) On the southwestern Western Tien-Shan (Western and Central Uzbekis$\tan$ ), there is a periodic recurrence of a group of strong earthquakes with the main shock of magnitude $M \geq 6.5$, which occur approximately synchronously with planetary seismicity processes.

5) Deviations from the general regularity of grouping Gazli strong earthquakes in the seismic regime of the region, associated with natural and technogenic events, were found. Forty years of constant gas pumping in the Gazli fields, underground nuclear explosions, crack formation processes, and absence of tangible earthquake in epicentral region of Gazli earthquakes for more than 40 years could become powerful triggers of three Gazli tectonic earthquakes of 1976 and 1984 with $\mathrm{M}=7.0,7.2$ and 7.3.

\section{Acknowledgements}

This work is supported by the state program of fundamental research under the "Study of the regularities of the development of the seismotectonic process in active seismic zones of Uzbekistan based on modern geodynamic models of Central Asia" grant.

\section{Conflicts of Interest}

The authors declare no conflicts of interest regarding the publication of this paper.

\section{References}

[1] Sitdikov, B.B. (1985) Neotectonics of the Western Tien-Shan. Fan, Tashkent, 144 p.

[2] Babadzhanov, T.L. and Mordvintsev, O.P. (2001) Features of the Structure of the Earth's Crust in Southwestern Uzbekistan. Journal Geology and Mineral Resources, No. 4, 42-46.

[3] Yakubov, D.Kh. and Yarmukhammedov, A.R. (1986) Geological-Tectonic Position and Conditions of Occurrence of Gazli Earthquakes. In: Gazli Earthquakes of 1976 and 1984, Fan, Tashkent, 34-41.

[4] Borisov, O.M. and Rogozhin E.A. (1986) Tectonic Position of the Source of the 1984 
Earthquake and Its Geological Manifestation. In: Gazli Earthquakes of 1976 and 1984, Fan, Tashkent, 41-59.

[5] Ulomov, V.I. (1986) The Gazli Earthquakes of 1976 and 1984. In: Gazli earthquakes of 1976 and 1984, Fan, Tashkent, 3-6.

[6] Zunnunov, F.Kh. (1985) Lithosphere of Central Asia According to Seismic Data. Fan, Tashkent, $108 \mathrm{p}$.

[7] Artikov, T.U., Ibragimov, R.S. and Ziyaudinov, F.F. (2012) Seismic Hazard of the Territory of Uzbekistan. LLC POLIMEXANIKA, Tashkent, 61-72.

[8] Usmanova, M.T. (2013) On the Issue of Late Cenozoic Tectonics, Seismicity of the Tien-Shan and Pamirs. Collection of Articles: Problems of Seismology in Uzbekistan No. 11. UD AN RUz, Tashkent, 48-54.

[9] Kondorskay, N.V. and Shebalin, N.V. (1977) New Catalog of Strong Earthquakes on the Territory of the USSR from Ancient Times to 1975. Part II. III. Central Asia and Kazakhstan. Science, Moscow, 198-296.

[10] Abdrakhmatov, K.E., Kalmetyeva, Z.A., Mikhailova, N.N. and Usmanova, M.T. (2008) Seismological Database of Central Asia as a Basis for the Study of Regional Geodynamic Processes (Catalog of Earthquakes in Central Asia from 2000 BC to 2005 AD). Collection Paper "Geodynamics of Inland Orogens and Geoecological Problems". Materials of the 4th International Symposium, Bishkek, 15-20 June 2008, 297-302.

[11] Poleshko, N.N., Aristova, I.L., Mukambaev, A.S. and Kulikova, G.O. (Edited by Mikhailova N.N.) (2017) Catalog of Strong Earthquakes in Central Asia from Ancient Times to 2017. Almaty. https://www.kndc.kz

[12] Catalogs of Earthquakes on the Territory of Uzbekistan (2000-2015) Complex Expedition of the Institute of Seismology of the Academy of Sciences of the Republic of Uzbekistan.

[13] Ibragimov, R.N., Nurmatov, U.O. and Ibragimov, O.R. (2002) Seismotectonic Method for Assessing Seismic Hazard and Issues of Seismic Zoning. In: Seismic Zoning and Earthquake Forecast in Uzbekistan, Gidroingeo, Tashkent, 59-74.

[14] Usmanova, M.T. and Sattarova, A.M. (2019) Some Patterns of Seismicity in Central and Western Uzbekistan. Periodic Scientific and Technical Journal of the National Nuclear Center of the Republic of Kazakhstan, Bulletin of NNC RK, No. 2, 88-97.

[15] Ibragimov, R.N. and Abdullabekov, K.N. (1974) On the Periodicity of Strong Earthquakes in the Western Tien Shan. Uzbek Geological Journal, No. 4, 42-45.

[16] Ibragimov, R.N., Sadykov, Yu.M., Khodzhaev A.K. and Nurmatov, U.O. (2011) Map of Seismogenic Zones in Uzbekistan and Adjacent Territories. M: 1: 600000. Tashkent: State. Scientific. Enterprise "Cartography" of the State Committee of the Republic of Uzbekistan for Land Resources, Geodesy, Cartography and State Cadastre, 2011, Circulation of 500 Copies.

[17] Gmurman, V.E. (2005) Probability Theory and Mathematical Statistics. Higher Education, Moscow, $384 \mathrm{p}$.

[18] Usmanova, M.T. (2004) On Seismic Models of the Realization of Strong Earthquakes in the Western Tien Shan (On the Example of Western Uzbekistan). Journal Geology and Mineral Resources, No. 2, 33-37.

[19] Usmanova, M.T. (2011) About Geodynamic Models and Seismicity of Central Asia. Annual Journal Catalog of Seismic Forecasting Observations on the Territory of Azerbaijan, 138-145.

[20] Yakovleva, I.B., Yakovlev, V.I. and Abdieva A. (1984) Spatio-Temporal Features of 
the Seismic Regime of the South Fergana Seismically Active Zone in Collection. Methods for Determining Seismic Hazard. Shtiintsa, Kishinev, 11-23.

[21] Kalmetyeva, ZA. (2005) Seismicity: Spatial-Temporal Distribution, Focal Mechanisms and the Nature of Earthquakes. Modern Geodynamics of Intracontinental Collisional Mountain Building (Central Asia). Scientific World, Moscow, 136-157.

[22] Abdullabekov, K.N. and Usmanova, M.T. (2003) Features of Manifestation of Strong Earthquakes in Time and Space. Reports of the Academy of Sciences of the Republic of Uzbekistan, No. 3, Fan, Tashkent, 60-64.

[23] Usmanova, M.T. (2016) About Modern Seismic Activation of the Territory of Central Asia. In: Reports of the International Conference "Actual Problems of Modern Seismology" Dedicated to the 50 th Anniversary of the Institute of Seismology of the Academy of Sciences of the Republic of Uzbekistan, OOO "MUXAMMAD POLIGRAF", Tashkent, 120-125.

[24] Kamchybekov, M.P., Usmanova, M.T., Frolova, A.G., et al. (2017) Kan Earthquake on July 19, 2011. In: Sat. Annual Collection "Earthquakes of Northern Eurasia for 2011", Science, Moscow, 379-391.

[25] Usmanova, M.T., Dzhuraev, A., Frolova, A.G., Nurmatov, U.A., Ikramova, D.A. and Sattarova, A.M. (2019) Tuyabuguz Earthquake on May 25, 2013 with KR = 14.1, ms $=5.2$, I0 $=7$ (Pritashkent District, Uzbekistan, Jizzakh Region). In: “Earthquakes of Northern Eurasia” for 2013, Obninsk, Russia, Issue No. 22 (2013), 397-409. https://doi.org/10.35540/1818-6254.2019.22.35

[26] Usmanova, M.T., Dzhuraev A., Shermatov, M.Sh., Frolova, A.G. and Sattarova, A.M. (2019) Marzhanbulak Earthquake on May 26, 2013 with $\mathrm{KR}=15.0$, MS = 5.9, I0 $=8$ (Uzbekistan, Jizzakh Region). In: “Earthquakes of Northern Eurasia” for 2013, Obninsk, Russia, Issue No. 22 (2013), 409-421. https://doi.org/10.35540/1818-6254.2019.22.36

[27] Avagimov, A.A., Zeigarnik, V.A., Nikolaev, A.A., Sobolev, G.A., et al. (2005) Seismicity Induced by Natural and Technogenic Processes. In: Modern Geodynamics of Areas of Intracontinental Collisional Mountain Building (Central Asia), Scientific World, Moscow, 224-232. 